\title{
Environmental Technology Platform Architecture for In Situ Monitoring Forest Areas of Amazonian region - A case study in Maiandeua Island, Brazil
}

\author{
Otavio Andre Chase ${ }^{1}$, Andre das Neves Carvalho ${ }^{2}$, Marcos Henrique Kumagai \\ Sampaio $^{3}$, José Felipe Souza de Almeida ${ }^{4}$, Carlos Tavares da Costa Junior ${ }^{5}$ \\ ${ }^{1}$ Universidade Federal do Pará (UFPA), Instituto de Tecnologia (ITEC), Programa de Pós-Graduação em \\ Engenharia Elétrica (PPGEE), Brazil. E-mail: otavio.chase@icloud.com \\ ${ }^{2}$ Biodiversity Research Consortium Brazil-Norway (BRC).E-mail: anc.ambiental@gmail.com \\ ${ }^{3}$ Universidade Federal do Pará (UFPA), Instituto de Tecnologia (ITEC), Programa de Pós-Graduação em \\ Engenharia Elétrica (PPGEE), Brazil.E-mail: mhsampaio@gmail.com \\ ${ }^{4}$ Universidade Federal Rural da Amazônia (UFRA), Instituto Ciberespacial (ICIBE), Laboratório de Sistemas \\ Ciberfisicos (LASIC), Brazil; E-mail: felipe.almeida@ufra.edu.br \\ ${ }^{5}$ Universidade Federal do Pará (UFPA), Instituto de Tecnologia (ITEC), Programa de Pós-Graduação em \\ Engenharia Elétrica (PPGEE), Brazil.E-mail: cartav@ufpa.br
}

\begin{abstract}
This research presents the architecture of a low-cost environmental technology platform for in situ monitoring fire risk characteristics of the Maiandeua Island at Amazonian, during the year 2013. This isle is a case study of the anthropized forest area, whose goal is to characterize the climatic behavior with environmental variables of temperature and humidity, all to identify environmental impacts on human health and biodiversity of the forest. The BRASSEN (Brasil System Sensor) platform contains an embedded expert system to detect the risk or without risk (safety) of fire at inhabited forest environments. The results of empirical experiments with this platform are provided. The period of highest understorey fire risk occurs between the months of June and November. Therefore, this work considers a novel study in IN-SITU (local) technologies in inhabited forest areas.
\end{abstract}

Keywords: - Environmental Monitoring, Environmental Technology, Forest Areas, System Integration.

\section{INTRODUCTION}

The Amazonian region, with predominantly tropical climate, the forest areas tend to be more humid than inhabited areas, even if the dew point is approximately equal [1]. The term anthropized forest used to refer generally to any transformation that produces the man on the forest environment, such as urbanization, agriculture, forestry, however, always predominating the forest area. Recent drought events underscore the vulnerability of Amazon forests to understorey fires [2], i.e., when there is a sudden drop in humidity, followed by several days without rain, the dryness of the air between the ground and the tree canopy makes the forest environment easily susceptible to fire occurrence. When this drought event occurs, increases the risk to the integrity of biodiversity, thereby making extreme environment.

Understorey forest fires burned more than $85.500 \mathrm{~km} 2$ between 1999 and 2010 ( $2.8 \%$ of all forests). Forests that burned more than once accounted for 16 per cent of all understorey fires [2]. The understorey fires are not easily detected by satellite with remote sensing [3]. Soon the use of IN-SITU monitoring based on environmental technology platform becomes a much-needed resource for the detection of forest fire risk [4].

The risk of fire behavior, for example, is to detect high temperatures and low humidity in the forest area; this indicates a high risk of fire. The integration of information these environmental variables in a ruleknowledge is a vital challenge to achieve integrated information of sensors for use with math an empirical model of their relationships. The advantage of detecting these forest fire risks early is so that we can prevent and avoid possible environmental accidents, so that such situations do not spread to the inhabited area.

The issue of global climate change is increasingly relevant in the context of a population of over seven billion people whose activities have been altering the surface characteristics such as vegetation cover, and the concentration of gases that interact strongly with radiation in the atmosphere [6]. According to the IPCC (Intergovernmental Panel on Climate Change) report, the people who will suffer most certainly will be the cities in the development of countries, especially tropical countries [7]. In these cases, the systems that can 
characterize environmental behaviors if they do very important, because these places do not have historical data of environmental variables to use as sources for prediction models and pattern recognition.

The environmental technology platform developed in this paper differs from an environmental monitoring system, because it has the resources to acquire simultaneously to multiple environmental variables and expert analysis of the information acquired by an embedded expert system, whose goal is to identify environmental conditions that offer risk or security forest fire in Maiandeua Island. The temperature and humidity sensors used in data acquisition of environmental variables. The temperature and relative humidity of the air determine the primal environmental factors, which influence human comfort, biodiversity and agricultural activities [5].

The distinctive feature of the proposed work is to develop an architecture of a sensing platform that integrates the knowledge of sensors, embedded computing, expert systems of forest fire risk and the environmental systems in a single study; to present an integrated solution. We present our findings by providing an overview of environmental technologies to promote sustainable management of resources in the Amazonian region. We hope that our work encourages others to develop similar highly-integrated systems for other types of ecosystems and forest fire risk applications.

\section{LITERATURE REVIEW}

Monitoring consists of repeated observations of environmental variables, whose purpose is defined according to a prior planning over time and space, using comparable methods, standardized and quantitative and qualitative. For example, the monitoring and study of the influence of temperature and humidity on thermal comfort and agricultural production [8]. The projects of environmental monitoring systems are focused primarily on electric power consumption, embedded computing, connectivity and low cost [19] [20]. Since the second half of the 2000 there has been the growth of environmental monitoring systems based on embedded systems and wireless communication networks in applications to: environmental [21], health [22], dangerous natural environments [23], renewable energy production [24], connectivity in the industry [25] and military defense technologies [26].

Previous research related to environmental monitoring of rural areas includes humidity sensor networks for forests [27], the use of wireless sensor networks (WSN) for evaluation of animal health in closed shelters [28], or conduct studies on how to develop WSN for outdoor environments [19]. Others use Wireless Multimedia Sensors Networks (WMSN) for Rural and Forest Fire Detection, through analysis of captured images to detect the frequency of pixels related to the fire [29].

Environmental Technology (ET) is the application of one or more of environmental science, green chemistry, environmental monitoring and electronic devices to monitor, model and conserve the natural environment and resources, and to curb the negative impacts of human involvement. The term is also used to describe sustainable energy generation technologies such as photovoltaics, wind turbines, hydrogen, bioreactors, etc. Sustainable development is the core of environmental technologies [30]. This literature review has revealed that there is no existing knowledge on the effect of weather conditions on in situ forest fire risk. The Maiandeua island has been chosen as the locality for this small scale study, because having the highest annual solar radiation in the Amazonian region and the major averages of temperature and humidity of Brazil [8].

\section{BRASSEN ENVIRONMENTAL TECHNOLOGY ARCHITECTURE}

The Figure 1 shows the BRASSEN fixed at their point in "Lagoa da Princesa" for the data acquisition of temperature, relative humidity and dew point. The results are distributed to a communication network with a supervisory system. The overall functionality of the BRASSEN is provided through a combination of hardware and software. The architecture is based on a data-flow model (Figure 3) and included hardware components (Figure 4). Their plastic case is rated at IP66 and provides dust, water and thermal protection and mechanical shock absorption. The BRASSEN has the robustness to operate in extreme environmental conditions, performs all the functions of a wireless sensor system, and has the task of analyzing fire risk in the forest by an expert system, which contains knowledge of the standards related to environmental variables of temperature, relative humidity and your relations with inhabited forests in the Amazon. The sensory platform works through communication between the sensing module and supervisory system. 


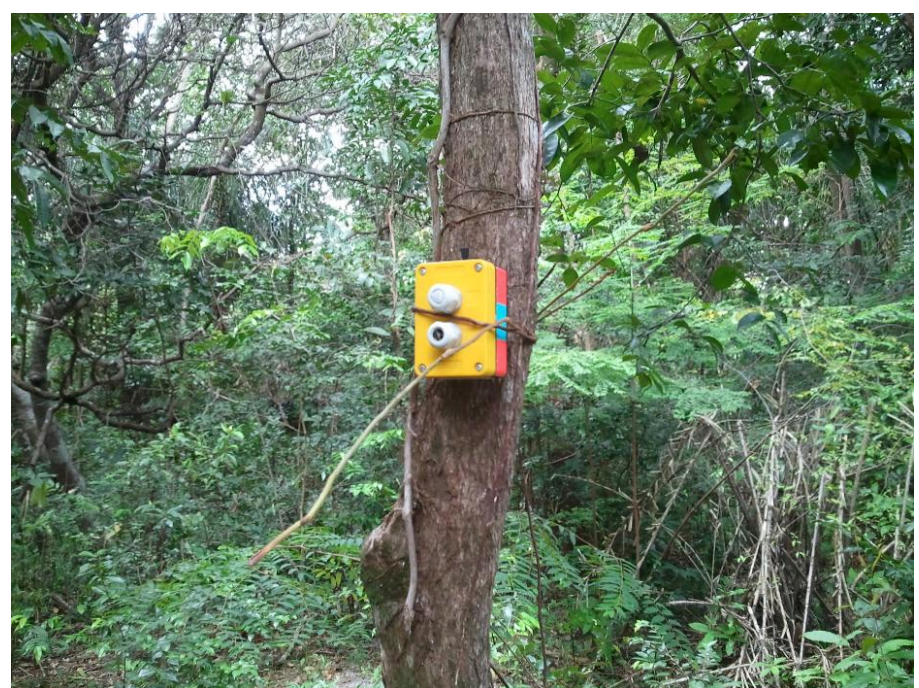

Figure 1. BRASSEN fixed to a tree with a high canopy (3.0m), in a height of $1.50 \mathrm{~m}$ from the floor.

This condition featuring a forest of understorey type.

The sensory module hardware (Figure 2) has the following devices - SHT75 a 14 bits digital high precision sensor of temperature and humidity; an embedded computer is a PIC18F252 8 bits microcontroller; The IEEE 802.15.4 wireless communication module [10].

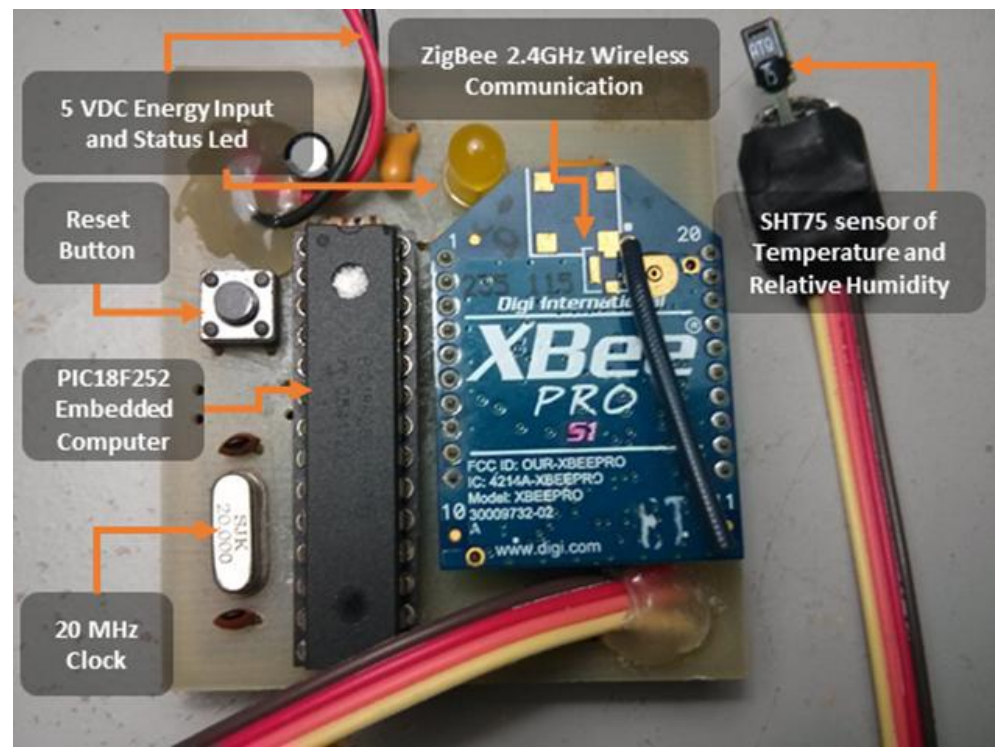

Figure 2. The Hardware Integration of Sensory Module, the board has dimensions of approximately

$$
4.5 \mathrm{~cm} \times 4.5 \mathrm{~cm} \text {. }
$$

The SHT75 is a 14 bits digital high precision sensor of temperature and humidity, with digital data output (2-wire interface), which covers the dynamic range of $-40^{\circ} \mathrm{C}$ to $125^{\circ} \mathrm{C}$ for the temperature, and 0 to $100 \%$ for the relative humidity [11].

The Zigbee (IEEE 802.15.4) module, whose the signals with the data captured by the sensors are transmitted by wireless communication. This micro transceiver operates at $2.4 \mathrm{GHz}$ in bidirectional mode and on half-duplex encrypted channel of data flow. The communication device used here can reach up to 100 meters, in indoor environments and 1 Kilometer in open environments. Thus, we chose to use this communication system, mainly due to its characteristics of reliability, self-healing, support for large numbers of nodes, easy interfacing with microcontrollers, low power consumption, encryption for the data channel and low cost.The Li-Ion (Lithium-Ion) battery, whose configuration is 5 Volts, and current load with 8.400 milliamperes per hour (mAh). The sensor captures information 3 minutes per day, the first minute at 9:00 am, the second minute at 15:00 pm, and the third minute to 21 hours. The sensor captures information 3 minutes per day, the 
first minute at 9:00 am, the second minute at 15:00 pm, and the third minute to 21 hours. With this, the platform is an autonomous power for about four months, and then only need three recharges during the year. The battery takes six hours to recharge

The embedded computer that manages all devices on the sensing platform is a PIC18F252 8 bits microcontroller [12], with clock of $40 \mathrm{MHz}$ and 2-wire interface port for communicating with the SHT75 Sensor, the transmitter (TX) and emitter (RX) serial ports for communicating with the Zigbee module. The microcontroller scheduled in the state of low power consumption and is activated by the supervisory system through receives Wake-Up signal of the Zigbee communication module daily at 9:00 am, 15:00 pm and 21:00 pm. The Wake-Up signal transmitted by the supervisory system. The architecture is based on a data-flow model (Figure 3) and has the three expert system functions:

- Function 1: the embedded computer receives the data from sensor SHT75 and performs the treatment of this information (Function 1);

- Function 2: computes the Angstron Index (B) from the collected data by rules of the type IF - THEN with basis on table 1 (Function 2);

- Function 3: sends messages to the supervisory system (Function 3), whose goal is to inform if there forest fire risk.

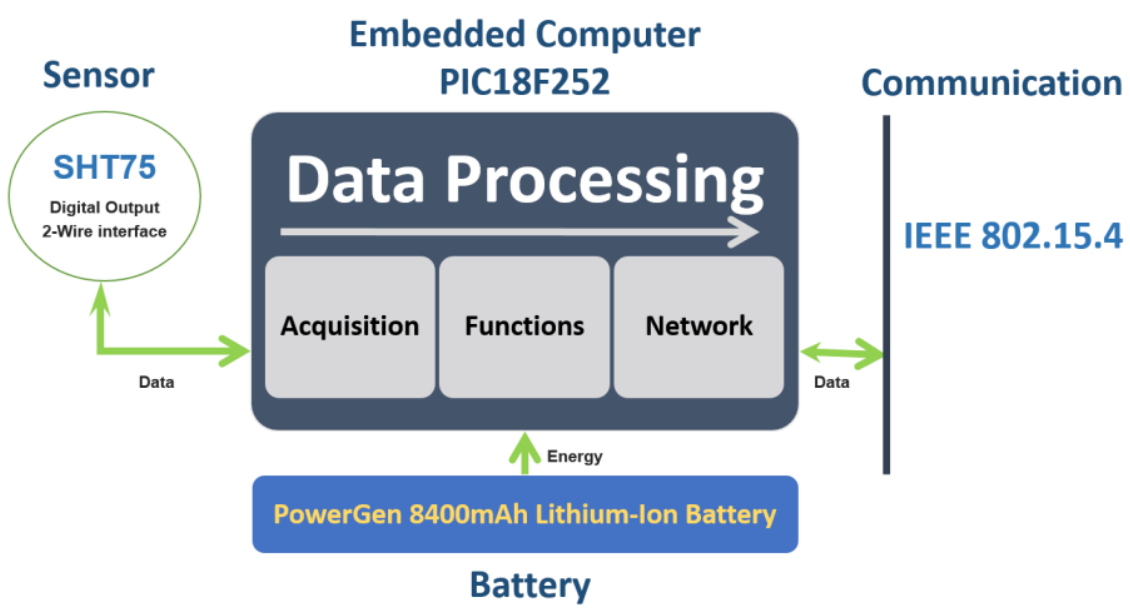

Figure 3. The Data Flow Architecture of BRASSEN

To detect behaviors related to fire risk [4] is using Angstron index (B):

$$
B=0,05 \times R H-0,1 \times(T-27)
$$

This index (B) developed in Switzerland in the 1950s is based on data mainly air temperature (Ta) and relative humidity $(\mathrm{RH})$, both measured daily at 15:00 hours. It is a non-cumulative and dimensionless index, when the index value is less than 2.5 , then there is a risk of fire, that is, the day will be an opportune time for occurrence of forest fires (see table 1).

Table 1. Levels of Forest Fire, Risk and alert

\begin{tabular}{|c|c|}
\hline B & Risk Level Alert \\
\hline $\mathrm{B} \geq 3$ & Low Risk \\
\hline $2.5<\mathrm{B}<3$ & Medium Risk \\
\hline $\mathrm{B} \leq 2.5$ & High Risk \\
\hline
\end{tabular}

The supervisory system (Figure 4) receives data via the communication interface IEEE 802.15.4 Zigbee standard (hardware installed on the notebook). The software developed in C++ language. In this system, there are processing two threads, one for data acquisition and sampling of the sensing module, and the other to 
record this information in a file. The data and graphs of the evolution versus time for temperature and humidity are displayed on the screen. The system generates a file of recorded data, which contains the array of data acquisition for temperature, humidity, Angstron Index, date and time.

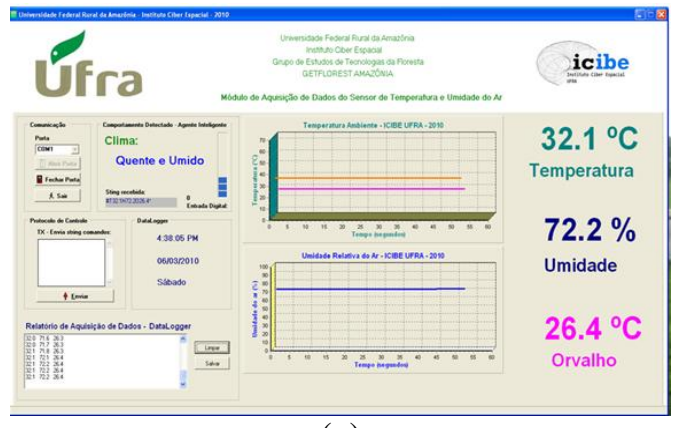

(a)

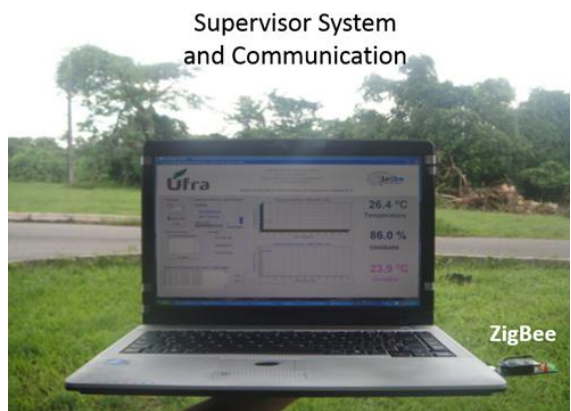

(b)

Figure 4. Supervisor System (a) and Notebook as with ZigBee Wireless Communication Module (b).

In other studies, with research related to monitoring in-situ there is concern with the simulation and sensor networks for forests or rural areas [14], while others are concerned with new mathematical or computational models of thermal comfort in rural or anthropogenic areas [15]. While the study in this paper proposes an architecture of a BRASSEN that supports environmental extreme cases, such as understorey fires.

\section{TEST SITE AT MAIANDEUA ISLAND}

The investigations took place in an inhabited area of the Maiandeua Island at Amazonian Region (State

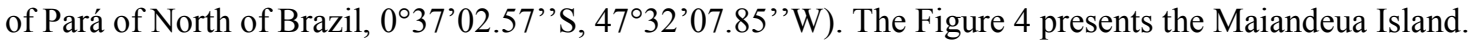

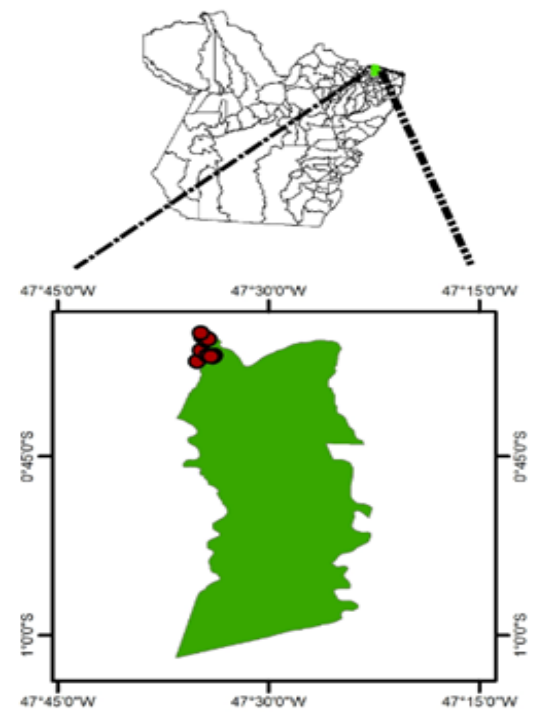

Figure 5. Localization and area of Maiandeua Island of Amazonian.

Since the 1980s there has been an increase in Maiandeua population, which led to the advancement of urbanization of the island. Also prohibited the use of motor vehicles, but there is strong pressure from residents for the initial release for motor vehicles and construction of paved trails. Since the early 2000s, deforestation and urbanization of some areas of the island has been noticed that these places there was a rise in temperature and diseases related to thermal discomfort, such as viral infections, colds and respiratory problems [16]. The experimental characterization was organized as follows: 1 (one) place from 6 (six) in the island was selected to be made the data acquisition of temperature and humidity. The places chosen are the red dots seen in fig. 4, this is the area, which suffered most deforestation and urbanization, all this by being near the sea (Atlantic Ocean) and facilitate transport, trade and tourism. 
In this work the emphasis is on data acquired in the "Lagoa da Princesa" (Pond of the Princess), as shown in fig. 5. This area is an example of an understorey fires in the forest. The Figure 1 shows the BRASSEN fixed at their point in "Lagoa da Princesa" for the data acquisition of temperature, relative humidity and Angstron Index (B).

\section{RESULTS}

In 2013 the average of temperature and relative humidity was $27.93^{\circ} \mathrm{C}$ and $81.78 \%$ respectively. The Figure 6 shows the evolution of temperature and humidity during the year 2013.

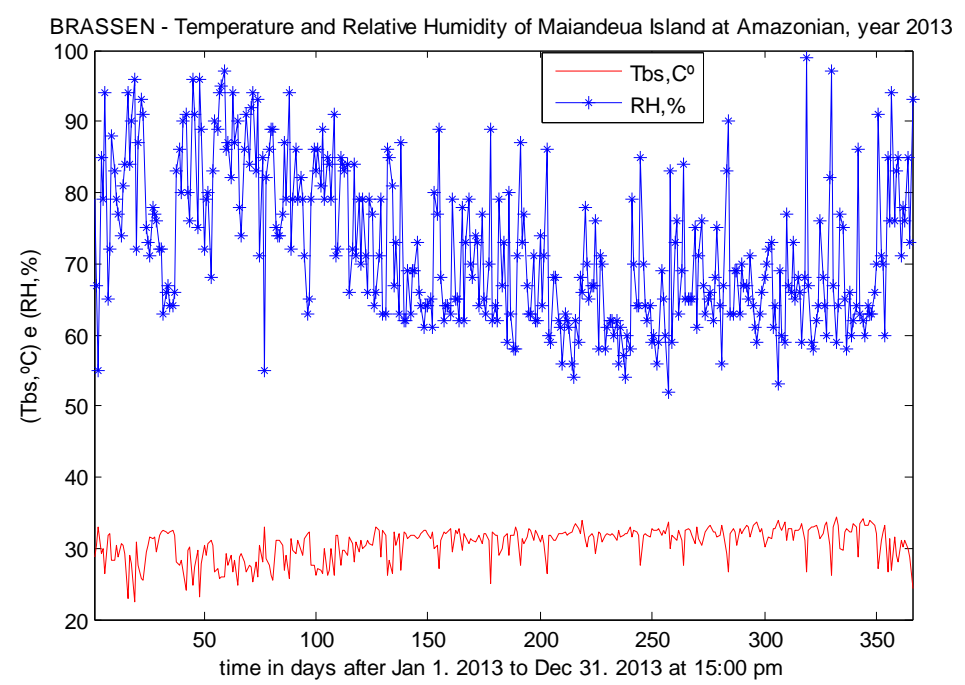

Figure 6. Evolution of temperature and humidity for the year 2013 at 15:00 pm.

The Figure 7 shows the evolution of an Angstron Index for estimate the forest fire risk. The temperature and relative humidity measured in the forest area proved slightly greater between the months of June and October (mean of temperature: $28.32^{\circ} \mathrm{C}$ and average relative humidity: $79.19 \%$ ).

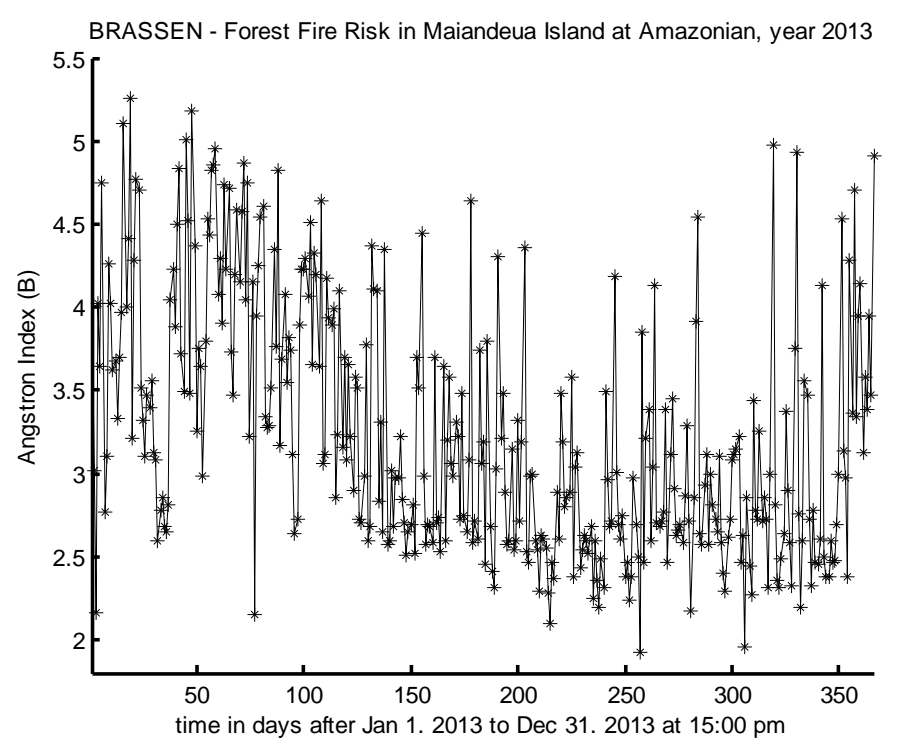

Figure 7. Evolution of Angstron Index (B) for the year 2012 at 15:00 pm.

In the other months of the year the temperature and relative humidity (mean of temperature: $27.7^{\circ} \mathrm{C}$ and relative humidity average: $83.30 \%$ ) are more mild (rarely the temperature is lower than $22^{\circ} \mathrm{C}$ ), on average, being the period from December to May (between years 2013/2012) the months with the lowest average. The period of highest understorey fire risk occurs between the months of June and November. 


\section{CONCLUSION}

Spatially dense real-time environmental monitoring is critical for protecting people and livestock from the extremes of environmental variability, such as the thermal discomfort we consider here. Furthermore, monitoring builds up an archive of past conditions, which can be both to improve real-time assessment methods and to influence societal decision-making.

The analysis of forest ecosystems by BRASSEN sensory platform obtained reliable results. The objective is to explain the relationships at the level of traditional communities in the Amazon between the social sciences, natural sciences, and man's relationship with nature, including how decisions involve the use of technology to exploit natural resources [17]. Studies of this kind are increasingly important and necessary to understand how, in recent years, there has been the relationship of nature and society and its productive means [18]. Advances for IN SITU monitoring in regions of the Amazonian, especially the understorey forests, provides a significant development in the understanding of climate effects on inhabited areas in the forest, which directly influences the biodiversity and human health. A better understanding of the interactions between the environment and living beings, reflected in their behavior and welfare, it becomes a source of strategies to minimize the effect of climate on them.

The BRASSEN will improve with more sensors, especially air pollution sensor, and the sensor soil moisture, whose purpose is to know the characteristics of other meteorological variables and their influences in the island's environment. The use of this information on environmental risks, particularly the risk of forest caught fire, resulting in the formation of an academic basis for the creation of other technological solutions to improve the triad environment, economy and society.

\section{REFERENCES}

[1] Chase, O. A.; Sampaio, M.H.K.; Brito-de-Souza, J.R.; J. Felipe Almeida. Data Acquisition System: An Approach to the Amazonian Environment, IEEE Latin America Transactions, 10(2), 1616 - 1621, doi: 10.1109/TLA.2012.6187606.

[2] Morton, D. C.; Le Page, Y.; DeFries, R.; Collatz, G. J.; Hurtt, G.C.. Understorey fire frequency and the fate of burned forests in southern Amazonia, Phil Trans R Soc B, vol. 368, no. 1619 20120155, April 22, 2013.

[3] Morton, D.C., Nagol, J.; Carabajal, C.C.; Rosette, J.; Palace, M.; Cook, B.D.; Vermote, E.F.; Harding, D.J. ; North, P.R. Amazon forests maintain consistent canopy structure and greenness during the dry season, Nature 506, 221-224 (13 February 2014), doi:10.1038/nature13006.

[4] Chase, O.A.; J. Felipe Almeida; Sampaio, M.H.K.; Brito-de-Souza, J.R. Sensory Platform Architecture Based on Cyberphysical Systems for Climate Behaviors Detecting in Urban Forest Environments, IEEE Sensors Conference, p. 1567-1570, doi: 10.1109/ICSENS.2011.6126899.

[5] Barradas, V.L. Air temperature and humidity and human comfort index of some city parks of Mexico City, International Journal of Biometeorology, Jun; 35(1):24-8, MEX, 1991.

[6] INTERGOVERNMENTAL PANEL ON CLIMATE CHANGE IPCC. "Climate Change 2001: the scientific basis IPCC WG I TAR”. Cambridge: Cambridge Univ. Press. 881p, GBR, 2001.

[7] U. Melo, "Climate Change: Defense and Intelligence", Brazilian Intelligence Magazine, n. 5, ISSN: 1809-2632, Brasília-DF, ABIN, BRA, 2009.

[8] Chase, O. A.; J. Felipe Almeida; Brito-de-Souza, J.R.; Tavares-da-Costa-Junior, C. Sensory Platform Architecture for IN SITU Monitoring the thermal comfort in Rural Environments - The Case Study at Federal Rural University of Amazonian, Brazil. Measurement (London. Print), v. 58, p. 294-300, doi: doi:10.1016/j.measurement.2014.08.031.

[9] Lee, E.A. Cyber Physical Systems: Design Challenges, International Symposium on Object / Component / Service-Oriented Real-Time Distributed Computing (ISORC), May 6, 2008 Orlando, FL, USA, 2008.

[10] Product Manual v1.x.1x - ZigBee Protocol, 90000866_A, 2007.

[11] SENSIRION. Datasheet SHT7x - Humidity and Temperature Sensor IC. 2011. Available online: http://www.sensirion.com/fileadmin/user_upload/customers/sensirion/Dokumente/Humidity/Sensirion_H umidity_SHT7x_Datasheet_V5.pdf (accessed on: 3. 1.2016).

[12] MICROCHIP. PIC18FXX2 Datasheet. $2010 . \quad$ Available online: http://www.microchip.com/wwwproducts/Devices.aspx?dDocName=en010276 (accessed on: 09. May. 2010 . 
[13] MAXIMINTEGRATED. Understanding the IP (Ingress Protection) Ratings of iButton Data Loggers and Capsule. Application Note 4126, $2007 . \quad$ Available online: http://pdfserv.maximintegrated.com/en/an/AN4126.pdf (Access on: 14.01.2015)

[14] Shinghal, K.; Noor, A.; Srivastava, N.; Singh, R. Intelligent Humidity Sensor for Wireless Sensor Network Agricultural Application. International Journal of Wireless \& Mobile Networks (IJWMN) Vol. 3, No. 1, doi: 10.5121/ijwmn.2011.3111.

[15] Ingraham, R.H.; Gillette, D.D.; Wagner, W.D. Relationship of Temperature and Humidity to Conception Rate of Holstein Cows in Subtropical Climate. American Dairy Science Association. Elsevier, Volume 57, Issue 4, Pages 476-481, doi: http://dx.doi.org/10.3168/jds.S0022-0302(76)84491-8.

[16] ONO, H.S.P.; Kawamura, T. Sensible Climates in Monsoon Asia, International Journal of Biometeorology, Vol. 35, n.XX, pp. 39-47, JPN, 1991.

[17] Tourinho, M. Community Management: Complexity Beyond Resources, 46th Conference of the Brazilian Society of Economics, Administration and Rural Sociology, Rio Branco-AC, BRA, 2008.

[18] Chase, O.A.; J. Felipe Almeida; Brito-de-Souza, J.R.; Tavares-da-Costa-Junior, C. Applying the use of Systemic View and Mobile Robotics in Engineering Education. Cyber Journals: Multidisciplinary Journals in Science and Technology, Journal of Selected Areas in Robotics and Control (JSRC), April Edition, 3, 4, Available online: http://www.cyberjournals.com/Papers/Apr2013/03.pdf (accessed on 23.07/2016)

[19] Kumar, A.; Kim, H.; Hancke, G. P. Environmental Monitoring Systems: A Review. IEEE Sensors Journal, 13, Issue 4, pp. 1329-1339, ISSN: 1530-437X, doi: 10.1109/JSEN.2012.2233469. Available online: http://ieeexplore.ieee.org/xpl/tocresult.jsp?isnumber=6451196 (accessed on 07.03.2016).

[20] Gaikwad, N.; Mistry, Y. Review on Environment Monitoring System and Energy Efficiency. International Journal of Engineering Research and Applications, 5, Issue 7, pp. 90-92, ISSN: 2248-9622. Available online: http://www.ijera.com/papers/Vol5_issue7/Part\%20-\%201/Q57019092.pdf (accessed on 07.03.2016).

[21] Othman, M.F.; Shazali, K. Wireless Sensor Network Applications: A Study in Environment Monitoring System. Procedia Engineering, International Symposium on Robotics and Intelligent Sensors 2012 (IRIS 2012), v. 41, pp.1204-1210, 2012.

[22] Castro, A.H.; Silva, G.M.; Araújo, R.S. Qualidade do Ar - Parâmetros de Controle e Efeitos na Saúde Humana: Uma breve revisão. Holos, 5, 0, pp.107-121, 14 nov. 2013.

[23] Moure, D. Use of Low-Cost Acquisition Systems with an Embedded Linux Device for Volcanic Monitoring. Sensors, 15, 8, pp.20436-20462, 19 ago. 2015.

[24] Fuentes, M. Design of an accurate, low-cost autonomous data logger for PV system monitoring using Arduino $^{\mathrm{TM}}$ that complies with IEC standards. Solar Energy Materials and Solar Cells, v.130, pp.529-543, nob. 2014.

[25] Gómez, A. Use of Single Board Computers as Smart Sensors in the Manufacturing Industry. Procedia Engineering, MESIC Manufacturing Engineering Society International Conference 2015, v.132, pp.153$159,2015$.

[26] MIL-EMBEDDED. Military Embedded Systems. Available online: http://mil-embedded.com/ (accessed on 07.5.2016).

[27] Bhavsar, A.R.; Arolkar, H.A. Wireless sensor networks: a possible solution for animal health issues in rural area of Gujarat, int. J. Enterprise Comput. Business Syste. - IJECBS 2(2) 2012, ISSN: 2230-8849, 2012.

[28] Pejovic, V. Rural Area Wireless Networks: Major Area Examination Writeup. Department of Computer Science, University of California, Santa Barbara, USA. Available online: http://www.cs.ucsb.edu/ veljko/docs/mae_writeup.pdf (accessed on 12.04.2016).

[29] Lloret, J.; Garcia, M.; Bri, D.; Sendra, S. A wireless sensor network deployment for rural and forest fire detection and verification, Sens. J. MDPI 9 (2009), pp.8722-8747, 1424-8220. Available online: http://dx.doi.org/10.3390/s91108722 (accessed on 15.05.2016).

[30] Wikipedia. Environmental Technology, Available online: https://en.wikipedia.org/wiki/Environmental_technology (accessed on: 20.07.2016). 